Article

\title{
Determinants of the Government Bond Yield in Spain: A Loanable Funds Model
}

\section{Yu Hsing}

College of Business, Southeastern Louisiana University, Hammond, LA 70402, USA;

E-Mail: yhsing@selu.edu; Tel.: +1-985-549-2086

Academic Editors: Marida Bertocchi and Rita L. D’Ecclesia

Received: 13 April 2015 / Accepted: 22 July 2015 / Published: 30 July 2015

\begin{abstract}
This paper applies demand and supply analysis to examine the government bond yield in Spain. The sample ranges from 1999.Q1 to 2014.Q2. The EGARCH model is employed in empirical work. The Spanish government bond yield is positively associated with the government debt/GDP ratio, the short-term Treasury bill rate, the expected inflation rate, the U.S. 10 year government bond yield and a dummy variable representing the debt crisis and negatively affected by the GDP growth rate and the expected nominal effective exchange rate.
\end{abstract}

Keywords: government debt; long-term interest rate; expected inflation; world interest rate; exchange rate; loanable funds model

JEL Classification: E43; E62; O52

\section{Introduction}

Before the Great Recession, Spain's debt-to-GDP ratio was as low as 39.06\% in 2008.Q1 due to rising tax revenues from the real estate bubble to cover increasing government spending. The Great Recession led to the real estate bust. Spanish banks went through financial turmoil as a result of violating accounting standards, hiding losses, misleading regulators and investors, and avoiding government supervision. With the help from the Troika, the Spanish government had to bail out large banks and incur huge government debt. The debt-to-GDP ratio had continued to rise to a high of $104.52 \%$ in 2014.Q2. Making things worse, Spanish government bonds were downgraded several times during 2010-2012, leading to a higher borrowing cost for the Spanish government. A relatively high debt-to-GDP ratio is 
expected to affect the long-term interest rate as the government is competing for limited funds with the private sector.

This paper examines the government bond yield for Spain based on a simultaneous-equation model consisting of the demand for and supply of loanable funds and has several different aspects. First, government debt as a percent of GDP is incorporated in the demand for loanable funds, and the world interest rate and the exchange rate are considered in the supply of loanable funds. Second, comparative static analysis is presented to determine the magnitude and sign of a change in an exogenous variable on the equilibrium government bond yield. Third, an advanced econometric method such as the EGARCH model is applied in estimating the parameters. Spain is selected as a case study mainly because it has not been adequately investigated.

\section{Literature Survey}

There has been continual interest in examining whether more government deficit/debt would raise the long-term interest rate, crowd out some of private expenditures, and dampen economic growth. The literature suggests that more government deficit/debt may or may not lead to a higher interest rate. Feldstein [1], Hoelscher [2], Wachtel and Young [3], Zahid [4], Thomas and Abderrezak [5], Miller and Russek [6], Raynold [7], Cebula [8], Vamvoukas [9], Ewing and Yanochik [10], and Saleh and Harvie [11] maintained that there is a positive relationship between the government deficit/debt and the interest rate. However, Kormendi [12], Hoelscher [13], Aschauer [14], Makin [15], McMillin [16], Evans [17-19], Gupta [20], Darrat [21,22], Findlay [23], and Ostrosky [24] indicated that more government deficit/debt would not lead to a higher interest rate. Barro [25-27] argued that more government deficit/debt would not increase aggregate demand because people would save more in order to pay more future tax to pay off government debt.

The loanable funds model has been employed in studying the impact of government deficits or debt on interest rates (Hoelscher [13], Tran and Sawhney [28], Thomas and Abderrezak [5], Cebula [8,29], Correia-Nunes and Stemitsiotis [30], García and Ramajo [31], Barnes [32], Hoelscher [13] developed a closed-economy loanable funds model, and Cebula [8,29] proposed an open-economy loanable funds model by considering the net capital inflow in the supply of loanable funds.

Reinhart, Reinhart, and Rogoff [33] examined government debt overhang episodes in advanced countries defined as the government debt/GDP ratio greater than $90 \%$ for five years or longer. The cumulative effect of government debt overhang episodes is to reduce the growth rate of real GDP by $24 \%$ after 23 years or an average of $1.2 \%$ per year. They also found that countries with high debt overhang episodes experienced growth-reducing effects but continued to have access to rather low real interest rates.

Lane [34] reviewed the European sovereign debt crisis, presented challenges of funding plans, and made several proposals to avoid future crises. These include the creation of a banking union with deposit insurance, regulation, and bank resolution policies, the introduction of a common area-wide "Eurobond" to reduce speculative attacks on national sovereign bonds, and the consideration of a more in-depth level of fiscal union to share some tax revenues and expenditures.

Checherita-Westphal and Rother [35] examined the effect of government debt on GDP growth for 12 euro area countries during a 40-year period. According to their findings, there was a nonlinear relationship between GDP growth and government debt. GDP growth and government debt had a 
positive relationship first and turned into a negative relationship when the debt-to-GDP ratio was between $90 \%$ and $100 \%$. The negative impact would probably begin at the $70 \%-80 \%$ ratio. The channels of the impacts of government debt on GDP growth went through public investment, total factor productivity, and private saving.

Gruber and Kamin [36] investigated the impact of government fiscal positions on government bond yields for OECD countries during 1988-2007. Their estimates showed that the worsening of U.S. fiscal positions would raise U.S. bond yields by 60 basis points. The impacts on other G-7 countries would be smaller.

Gruppe and Lange [37] showed that the Spanish and German government bond yields had a long-term stable relationship. But, they found that the relationship had a structural break at the beginning of 2009, suggesting that the financial market was somewhat efficient and foresaw a higher sovereign debt risk in Spain.

Poghosyan [38] analyzed the determinants of sovereign bond yields in 22 advanced countries. He found that a one percentage point increase in the government debt/GDP ratio resulted in a two base point increase in the government bond yield in the long run. In the short run, the sovereign bond yield deviated from the value based on the long-run fundamentals, but it adjusted about $50 \%$ of the deviation toward the fundamental value.

Moro [39] indicated that the European crisis could spread fast among the tightly integrated EMU countries via the financial or trade channel. In the short run, surplus countries should increase aggregate demand and allow the inflation rate and wages to rise. In the medium term, a successful resolution requires both a banking union and a fiscal union.

Using the German interest rate as a benchmark rate, Sibbertsen, Wegener, and Basse [40] examined whether bond yield spreads in Spain, France, and Italy may experience structural breaks. They found that there were breaks of the bond yield spread during 2006-2008 and that bond yield spreads rose substantially after 2008 mainly due to higher sovereign credit risk related to the sovereign debt crises. Furthermore, long memory behavior was found before and after the breaks.

Gómez-Puig and Sosvilla-Rivero [41] examined the causality and the contagion effect of EMU debt crisis for 11 EMU countries during 1999-2012. They found that there was evidence of contagion of the debt crisis as evidenced by the 41 new causality cases and the intensification of the causality in 42 out of 60 cases and that most breakpoints occurred after the Greek government admitted that its government debt and budget deficit were much worse than previously announced.

Gómez-Puig, Sosvilla-Rivero, and del Carmen Ramos-Herrera [42] investigated sovereign bond spreads using the German government bond yield for selected central and peripheral countries during 1999-2012. Variables considered include the local market sentiment, the regional market sentiment, the global market sentiment, the local macro fundamentals, the regional macro fundamentals, and the financial linkages. They found that local macroeconomic factors can only partially explain the increase in sovereign risk in central countries and that sovereign spread drivers increased their impacts during the crisis especially in the peripheral countries.

Based on times series techniques incorporating structural changes, Basse [43] tried to estimate sovereign credit risk in the EMU. He found that bond markets seem not to regard France as a core country. 


\section{The Model}

Suppose that the demand for loanable funds is negatively affected by the long-term interest rate and positively influenced by the short-term interest rate, the expected inflation rate, the percent change in real GDP, and government debt and that the supply of loanable funds is positively associated with the long-term interest rate, the percent change in real GDP, and the expected nominal effective exchange rate and negatively influenced by the short-term interest rate, the expected inflation rate, the world long-term interest rate, and a dummy variable representing the government debt crisis. In the extended open-economy loanable funds model, the demand for and the supply of loanable funds can be expressed as

$$
\begin{gathered}
F^{d}=D(L R, S R, E I, G Y, D E) \\
-++++ \\
F^{s}=S(L R, S R, E I, G Y, E X, W R, D U M)
\end{gathered}
$$

where

$F^{d}=$ the demand for loanable funds in Spain,

$F^{s}=$ the supply of loanable funds in Spain,

$\mathrm{LR}=$ the long-term interest rate in Spain,

$\mathrm{SR}=$ the short-term interest rate in Spain,

$\mathrm{EI}=$ the expected inflation rate in Spain,

$\mathrm{GY}=$ percent change in real GDP in Spain,

$\mathrm{EX}=$ the expected nominal effective exchange rate (An increase means expected appreciation of the Spanish currency.),

$\mathrm{DE}=$ government debt/GDP ratio in Spain,

$\mathrm{WR}=$ the world long-term interest rate, and

$\mathrm{DUM}=$ a dummy variable representing the government debt crisis.

Solving for the equilibrium long-term interest rate and loanable funds simultaneously gives

$$
\overline{L R}=\overline{L R}(D E, S R, G Y, E I, W R, E X, D U M)
$$

The partial derivatives of $\overline{L R}$ with respect to each of the exogenous variables are given by

$$
\begin{gathered}
\partial \overline{L R} / \partial D E=D_{D E} /|J|>0 \\
\partial \overline{L R} / \partial S R=\left(D_{S R}-S_{S R}\right) /|J|>0 \\
\partial \overline{L R} / \partial G Y=\left(D_{G Y}-S_{G Y}\right) /|J|>\text { or }<0 \\
\partial \overline{L R} / \partial E I=\left(D_{E I}-S_{E I}\right) /|J|>0 \\
\partial \overline{L R} / \partial W R=-S_{W R} /|J|>0 \\
\partial \overline{L R} / \partial E X=-S_{E X} /|J|<0
\end{gathered}
$$




$$
\partial \overline{L R} / \partial D U M=-S_{D U M} /|J|>0
$$

where $|J|$ is the Jacobian for the endogenous variables and has a positive value. Theoretically, the equilibrium long-term interest rate has a positive relationship with the government debt/GDP ratio, the short-term interest rate, the expected inflation rate and the world long-term interest rate, a negative relationship with the expected nominal effective exchange rate, and an ambiguous relationship with the percent change in real GDP.

\section{Empirical Results}

The data were collected from the IMF's International Financial Statistics. The Spanish government bond yield is selected to represent the long-term interest rate, and the Treasury bill rate is chosen to represent the short-term interest rate. The world long-term interest rate is represented by the U.S. government 10 year bond yield. The growth rate of real GDP is calculated based on the GDP volume index with 2010 as the base year. The expected inflation rate is a weighted average inflation rate of the past four quarters. The expected nominal effective exchange rate is the average of the past four nominal effective exchange rates. The dummy variable measuring the government debt crisis has a value of 1 during 2012.Q2-2012.Q3 and zero otherwise. The sample ranges from 1999.Q1 to 2014.Q2 and has a total of 62 observations.

Unit root tests on individual variables are performed. Based on the ADF test, the null hypothesis that each of the variables has a unit root cannot be rejected at the 5\% level. According to the Engle-Granger test on the regression residuals, the value of the test statistic is estimated to be -3.8972 , which is greater than the critical value of -3.2100 in absolute values. Hence, these variables are cointegrated and have a stable long-term relationship. For a detailed description of the Engle-Granger cointegration test, see Gujarati and Porter [44] (pp. 762-764). Note that the Engle-Granger cointegration model employed in this study may yield different results due to the degrees of freedom and the number of variables (Dickey, Jansen, and Thornton, [45]).

Table 1 presents estimated parameters and other related statistics. The EGARCH model is applied in empirical work. The EGARCH model is chosen in empirical study because it is superior to the GARCH model. In the GARCH model, volatility is an additive function of lagged innovations, the positive and negative error terms are assumed to have a symmetric impact on the volatility, and volatility reacts symmetrically to good and bad news. In the EGARCH model, volatility is a multiplicative function of the lagged error terms and responds asymmetrically to good and bad news, and the parameters are less restrictive and can have positive and negative values.

As shown, approximately $76.68 \%$ variation in the government bond yield can be explained by the seven right-hand side variables. All the coefficients are significant at the $1 \%$ level. The government bond yield is positively associated with the government debt/GDP ratio, the Treasury bill rate, the expected inflation rate, the U.S. 10 year government bond yield, and the dummy variable and negatively influenced by the growth rate of real GDP and the expected nominal effective exchange rate. 
Table 1. Estimated Regression of the Spanish Government Bond yield.

\begin{tabular}{ccc}
\hline Variable & Coefficient & z-Statistic \\
\hline Constant & 1.703914 & 0.813828 \\
Log(Debt-to-GDP ratio) & 1.768193 & 36.19707 \\
Treasury bill rate & 0.512903 & 47.96369 \\
GDP growth rate & -0.115279 & -24.96007 \\
Expected inflation rate & 0.071048 & 5.060756 \\
U.S. government bond yield & 0.070169 & 4.646330 \\
Log(Expected NEER) & -1.323987 & -3.116986 \\
Dummy variable & 0.670936 & 13.85305 \\
R-squared & 0.766844 & \\
F-statistic & 16.77381 & \\
Methodology & EGARCH & \\
Sample period & $1999 \mathrm{Q} 1-2014 \mathrm{Q} 2$ & \\
Sample size & 62 & \\
\hline
\end{tabular}

Dummy variable $=1$ during 2012.Q2-2012.Q3 and $=0$ otherwise; NEER $=$ the nominal effective exchange rate.

Specifically, if the log of the government debt/GDP ratio rises by 1 , the government bond yield would increase 1.7682 percentage points. When the Treasury bill rate increases 1 percentage point, the government bond yield would rise 0.5129 percentage points. As real GDP grows 1 percentage point, the government bond yield would decline 0.1153 percentage points. An increase in the expected inflation rate of 1 percentage point would cause the government bond yield to rise 0.0710 percentage points. As the U.S. 10 year government bond yield rises 1 percentage point, the Spanish government bond yield would rise 0.0702 percentage points. If the log of the expected nominal effective exchange rate rises by 1 unit, the Spanish government bond yield would decline 1.3240 percentage points. The government debt crisis during 2002.Q2-2002.Q3 caused the Spanish government bond yield to rise 0.6709 percentage points. In comparison, the positive impact of a higher government debt/GDP ratio on the government bond yield found in this study is consistent with the findings reported by Gruber and Kamin [36] and Poghosyan [38].

If the average inflation rate of the past four quarters is used to represent the expected inflation rate, the coefficient is positive and significant at the $1 \%$ level. The value of R-squared is 0.7323 , which is lower than the R-squared value reported in Table 1 . When the government bond yield in the euro area replaces the U.S. 10 year government bond yield, its positive coefficient of 0.5320 is significant at the $1 \%$ level. However, the coefficient of the expected nominal effective exchange rate has a positive significant sign mainly due to a high degree of multicollinearity.

\section{Conclusions}

This paper has examined the determinants of the Spanish government bond yield based on the loanable funds model. To find the equilibrium government bond yield, the demand for and supply of loanable funds are simultaneously solved, and a reduced-form regression is estimated. A higher government debt/GDP ratio, a higher Treasury bill rate, a lower GDP growth rate, a higher expected inflation rate, a higher U.S. 10 year government bond yield, a lower expected nominal effective exchange rate, or the government debt crisis is expected to cause the Spanish government bond yield to rise. 
There are several policy implications. Global variables such as the world long-term interest rate and the exchange rate affect the supply of loanable funds. As the spread between the Spanish government bond yield and the U.S. 10 year government bond yield increases, investors may be reluctant to purchase Spanish government bonds due to a higher risk. The expected decline of the value of the euro versus the U.S. dollar may suggest that investors would reduce the supply of loanable funds and raise the Spanish government bond yield. On the other hand, the declining trend of the expected inflation rate would reduce the Spanish government bond yield.

Fortunately, the Spanish government has taken measures to reduce government deficits and debt. These measures include cutting wages for civil servants, freezing pension increase, reforming the labor market, raising the retirement age from 65 to 67, passing of a Constitutional amendment to balance the budget during normal economic growth, reducing wind power subsidies, increasing tax on the wealthy, the tobacco tax, and the value added tax by 2 percentage points, and others.

\section{Conflicts of Interest}

The author declares no conflict of interest.

\section{References}

1. Feldstein, M. Government deficits and aggregate demand. J. Monet. Econ. 1982, 9, 1-20.

2. Hoelscher, G. Federal borrowing and short-term interest rates. South. Econ. J. 1983, 50, 319-333.

3. Wachtel, P.; Young, J. Deficit announcements and interest rates. Am. Econ. Rev. 1987, 5, 1007-1012.

4. Zahid, K.H. Government budget deficits and interest rates: The evidence since 1971 using alternate deficit measures. South. Econ. J. 1988, 3, 725-731.

5. Thomas, L.B., Jr.; Abderrezak, A. Long-term interest rates: The role of expected budget deficits. Public Financ. Q. 1988, 1, 341-356.

6. Miller, S.M.; Russek, F.S., Jr. The temporal causality between fiscal deficits and interest rates. Contemp. Policy Issues 1991, 9, 12-23.

7. Raynold, P. The impact of government deficits when credit markets are imperfect: Evidence from the interwar period. J. Macroecon. 1994, 16, 55-76.

8. Cebula, R.J. Impact of budget deficits on ex post real long-term interest rates. Appl. Econ. Lett. 2000, 7, 177-179

9. Vamvoukas, G.A.A. Note on budget deficits and interest rates: Evidence from a small, open economy. South. Econ. J. 1997, 63, 803-811.

10. Ewing, B.T.; Yanochik, M.A. Budget deficits and the term structure of interest rates in Italy. Appl. Econ. Lett. 1999, 6, 199-201.

11. Saleh, A.S.; Harvie, C. The budget deficit and economic performance: A survey. Singap. Econ. Rev. 2005, 50, 211-243.

12. Kormendi, R.C. Government debt, government spending, and private sector behavior. Am. Econ. Rev. 1983, 73, 994-1010.

13. Hoelscher, G. New evidence on deficits and interest rates. J. Money Credit Bank. 1986, 18, 1-17.

14. Aschauer, D.A. Does public capital crowd out private capital? J. Monet. Econ. 1989, 25, 171-188. 
15. Makin, J.H. Real interest, money surprises, anticipated inflation and fiscal deficits. Rev. Econ. Stat. 1983, 65, 374-384.

16. McMillin, W.D. Federal deficits and short-term interest rates. J. Macroecon. 1986, 8, 403-422.

17. Evans, P. Do large deficits produce high interest rates? Am. Econ. Rev. 1985, 75, 68-87.

18. Evans, P. Do budget deficits raise nominal interest rates? Evidence from six countries. J. Monet. Econ. 1987, 20, 281-300.

19. Evans, P. Are government bonds net wealth? Evidence for the United States. Econ. Inq. 1988, 26, 551-566.

20. Gupta, K.L. Budget deficits and interest rates in the US. Public Choice 1989, 60, 87-92.

21. Darrat, A.F. Fiscal Deficits and long-term interest rates: Further evidence from annual data. South. Econ. J. 1989, 56, 363-373.

22. Darrat, A.F. Structural federal deficits and interest rates: Some causality and cointegration tests. South. Econ. J. 1990, 56, 752-759.

23. Findlay, D.W. Budget deficits, expected inflation and short-term real interest rates: Evidence for the US. Int. Econ. J. 1990, 4, 41-53.

24. Ostrosky, A.L. Federal government budget deficits and interest rates: Comment. South. Econ. J. 1990, 56, 802-803.

25. Barro, R.J. Are government bonds net wealth? J. Polit. Econ. 1974, 82, 1095-1117.

26. Barro, R.J. Government Spending, Interest Rates, Prices, and Budget Deficits in the United Kingdom 1701-1918. J. Monet. Econ. 1987, 20, 221-247.

27. Barro, R. The Ricardian approach to budget deficits. J. Econ. Perspect. 1989, 3, 37-54.

28. Tran, D.T.; Sawhney, B.L. Government deficits, capital flows, and interest rates. Appl. Econ. 1988, 20, 753-765.

29. Cebula, R.J. Budget deficits and interest rates in Germany. Int. Adv. Econ. Res. 2003, 9, 64-68.

30. Correia-Nunes, J.; Stemitsiotis, L. Budget deficit and interest rates: Is there a link? International evidence. Oxf. Bull. Econ. Stat. 1995, 57, 425-449.

31. García, A.; Ramajo, J. Budget deficit and interest rates: Empirical evidence for Spain. Appl. Econ. Lett. 2004, 11, 715-718.

32. Barnes, B.J. A cointegrating approach to budget deficits and long-term interest rates. Appl. Econ. 2008, 40, 127-133.

33. Reinhart, C.M.; Reinhart, V.R.; Rogoff, K.S. Public debt overhangs: Advanced-economy episodes since 1800. J. Econ. Perspect. 2012, 26, 69-86.

34. Lane, P.R. The European sovereign debt crisis. J. Econ. Perspect. 2012, 26, 49-67.

35. Checherita-Westphal, C.; Rother, P. The impact of high government debt on economic growth and its channels: An empirical investigation for the euro area. Eur. Econ. Rev. 2012, 56, 1392-1405.

36. Gruber, J.W.; Kamin, S.B. Fiscal positions and government bond yields in OECD countries. J. Money Credit Bank. 2012, 44, 1563-1587.

37. Gruppe, M.; Lange, C. Spain and the European sovereign debt crisis. Eur. J. Polit. Econ. 2014, 34, S3-S8.

38. Poghosyan, T. Long-run and short-run determinants of sovereign bond yields in advanced economies. Econ. Syst. 2014, 38, 100-114. 
39. Moro, B. Lessons from the European economic and financial great crisis: A survey. Eur. J. Polit. Econ. 2014, 34, S9-S24.

40. Sibbertsen, P.; Wegener, C.; Basse, T. Testing for a break in the persistence in yield spreads of EMU government bonds. J. Bank. Financ. 2014, 41, 109-118.

41. Gómez-Puig, M.; Sosvilla-Rivero, S. Causality and contagion in EMU sovereign debt markets. Int. Rev. Econ. Financ. 2014, 33, 12-27.

42. Gómez-Puig, M.; Sosvilla-Rivero, S.; del Carmen Ramos-Herrera, M. An update on EMU sovereign yield spread drivers in times of crisis: A panel data analysis. N. Am. J. Econ. Financ. 2014, 30, 133-153.

43. Basse, T. Searching for the EMU core member countries. Eur. J. Polit. Econ. 2014, 34, S32-S39.

44. Gujarati, D.N.; Porter, D.C. Basic Econometrics, 5th ed.; McGraw-Hill: Boston, MA, USA, 2009.

45. Dickey, D.A.; Jansen, D.W.; Thornton, D.L. A primer on cointegration with an application to money and income. Fed. Reserve Bank St. Louis Rev. 1991, 73, 58-78.

(C) 2015 by the author; licensee MDPI, Basel, Switzerland. This article is an open access article distributed under the terms and conditions of the Creative Commons Attribution license (http://creativecommons.org/licenses/by/4.0/). 